\title{
Effect of Bunaphtine on right atrial repolarisation in man
}

\author{
R. FENICI, M. MARCHEI, F. BELLOCCI AND P. ZECCHI
}

From the Cardiovascular Laboratory, Department of Medical Pathology, Catholic University of Sacred Heart, Rome, Italy

Using a bipolar suction electrode technique, right atrial monophasic action potentials were recorded in 11 patients with recurrent attacks of paroxysmal atrial tachyarrhythmia.

The right atrial monophasic action potential total duration, measured at 90 per cent level of repolarisation, in sinus rhythm, ranged between 217 and 394 ms.

$N$ (2-diethylamine-ethyl) $N(n$-buthyl)-naphtamide (Bunaphtine) was administered by an intracardiac catheter at an average dosage of $1.78 \mathrm{mg} / \mathrm{kg}$ body weight in order to evaluate its effect on atrial repolarisation. Monophasic action potential recordings were performed during drug administration and thereafter every minute for an average observation period of $12 \cdot 2$ minutes. The drug induced a significant lengthening of atrial repolarisation (mean 18.4\%) strongly correlated with a significant reduction of relative repolarisation rate of phase 3 (RRR ph3). The effect was more obvious in patients with short repolarisation and was not correlated with significant variations in heart rate. When basic cycle length was maintained constant by atrial pacing an increase in total duration of right atrial monophasic action potential was seen. Administration of the drug was followed by an appreciable reduction of inhomogeneity of repolarisation as measured from different sites in the atrium. In 2 patients conversion from atrial fibrillation to sinus rhythm occurred during drug infusion with a progressive lengthening of right atrial monophasic action potential; this suggests that the antiarrhythmic properties of Bunaphtine are related to its direct effect on repolarisation. Thus, as far as atrial tissue is concerned Bunaphtine can be considered a Class 3 antiarrhythmic drug according to the classification of Vaughan-Williams.

$\mathrm{N}$ (2-diethylamine-ethyl) $\mathrm{N}$ (n-buthyl) naphtamide (Bunaphtine) $)^{1}$ is a new drug, the antiarrhythmic properties of which have been reported as being superior to those of quinidine (Beani, 1972), while circulatory side effects appear to be less; it does not significantly affect mean arterial pressure or coronary flow. In therapeutic doses it seems to be strictly cardioactive; only at toxic levels does it induce depression of the central nervous system (Beani, 1972).

Wide clinical use has proved the effectiveness of Bunaphtine in the treatment of both ventricular and supraventricular arrhythmias, either chronic or paroxysmal (Botti, 1972; Lotto and Lomanto, 1972; Masini et al., 1972; Franchini et al., 1974; Vegis, 1975). Good results have been obtained also in prophylactic and therapeutic use in patients with acute myocardial infarction (Botti et al., 1976).

Electrophysiological properties of Bunaphtine

1 1st. Farmacologico Malesci, Firenze, Italy.

Received for publication 29 November 1976 have been studied in vitro on guinea-pig and rabbit heart preparations by the microelectrode technique (Ferroni and Monticelli, 1973). The primary effects of the drug on action potentials of atrial myocardial cells are a reduction or disappearance of prepotentials, a prolongation of action potential duration, a significant reduction in heart rate, and an increase in amplitude of the action potential (Ferroni and Monticelli, 1973).

Electrophysiological studies in patients, carried out by His bundle electrogram and pacing techniques, have given some information on the effects of Bunaphtine on atrioventricular conduction (Scibilia et al., 1973; Grazi et al., 1974), but so far little information is available about its effect on myocardial refractory periods (Grazi et al., 1975).

The monophasic action potential recording technique using a suction electrode permits a good evaluation of the action potential duration and of the course of repolarisation (Hoffman et al., 1959; Shabetai et al., 1968; Olsson, 1971). While it cannot 
give reliable information about the depolarisation phase, it provides an exact measure of myocardial refractoriness and of rapid changes of this (Olsson, 1971). For this reason the monophasic action potential recording technique has been recommended for the accurate study of the electrophysiology of the arrhythmias and of the mechanisms of action of antiarrhythmic drugs in clinical practice (Gavrilescu and Cotoi, 1972; Olsson, 1972; Cabasson et al., 1975; Fenici et al., 1975). In previous observations (Fenici et al., 1974a, b) Bunaphtine was found to delay repolarisation of human atrial myocardial fibres. The present study was carried out in order to evaluate the effect of Bunaphtine on right atrial monophasic action potential in patients with recurrent paroxysmal supraventricular tachyarrhythmias, in the hope of providing a more rational basis for the clinical use of the drug.

\section{Patients and methods}

Eleven patients, 6 women and 5 men, all complaining of episodes of paroxysmal atrial tachyarrhythmia, were investigated, after informed consent had been obtained, during routine electrophysiological studies or diagnostic right heart catheterisation. In all cases except one (case 1) previous cardioactive treatment, if being given, had been discontinued at least 3 days before the procedure. All the patients, except case 1, were in sinus rhythm at the beginning of the investigation. Selected clinical data from the patients are presented in Table 1.
Right atrial monophasic action potential recordings were performed using a $7 \mathbf{F}$ gauge bipolar electrode catheter (USCI No 5623) modified to produce a suction electrode catheter as described in more detail elsewhere (Fenici et al., 1973). Absolute electrical safety of the patient was provided. Deriving a unipolar signal using a peripheral electrode, an intracardiac electrogram was obtained along with the monophasic action potential from the same recording site; this is useful for a correct evaluation of the quality of the monophasic action potential and of the level at which recording is accomplished (Olsson, 1971). For signal amplification HP 8811A bioelectrical amplifiers were used. Recordings were performed, together with continuous oscilloscopic monitoring, directly onto a magnetic tape recorder (HP 3960M), allowing easy data storage and playback in a time expanded or compressed mode, to improve data manipulation. Tracings were transferred onto photographic paper at 100 and $200 \mathrm{~mm} / \mathrm{s}$ paper speed. Suction applied was mainly $350 \mathrm{mmHg}$; it was discontinued every 2 minutes to avoid the danger of irreversible myocardial lesions (Olsson, 1971). All patients tolerated the procedure without any subjective discomfort or objective complication.

After a stable monophasic action potential recording had been obtained in basal conditions, an average dose of $1.78 \mathrm{mg} / \mathrm{kg}$ body weight of Bunaphtine was delivered, directly in the right atrium, over 1 to 2 minutes. Right atrial monophasic action potential was recorded continuously from the same site during drug administration and

Table 1 Selected data from patients

\begin{tabular}{|c|c|c|c|c|c|c|c|c|}
\hline $\begin{array}{l}\text { Case } \\
\text { No. }\end{array}$ & $\begin{array}{l}\text { Age } \\
(y)\end{array}$ & Sex & Diagnosis & Electrocardiogram & $\begin{array}{l}\text { Paroxysmal } \\
\text { arrhythmias }\end{array}$ & $K(\mathrm{mmol} / \mathrm{l})$ & Drugs & $\begin{array}{l}\text { Discontinued } \\
\text { before study }\end{array}$ \\
\hline 1 & 44 & $\mathbf{F}$ & $\begin{array}{l}\text { MS (operated); DC shock conversion } \\
\text { of AF with frequent relapse }\end{array}$ & SR-RAO-RVO & AFl-AF & Normal & $\begin{array}{l}\text { Digitalis } \\
\text { propranolol, } \\
\text { quinidine }\end{array}$ & $\begin{array}{l}3 \text { days } \\
\text { ND } \\
\text { ND }\end{array}$ \\
\hline 2 & 38 & $\mathbf{F}$ & Thyroid adenoma & SR-N & PAT & Normal & Propranolol & 10 days \\
\hline 3 & 49 & $\mathbf{F}$ & Palpitation & SR-N & PAF & Normal & None & - \\
\hline 4 & 46 & $\mathbf{F}$ & $\begin{array}{l}\text { ASD (foramen ovale); hypothyroidism, } \\
\text { hiatus hernia }\end{array}$ & SR-N & PAT & $3 \cdot 2$ & None & - \\
\hline $\begin{array}{l}5 \\
6 \\
7\end{array}$ & $\begin{array}{l}66 \\
40 \\
25\end{array}$ & $\begin{array}{l}\mathbf{M} \\
\mathbf{M}\end{array}$ & $\begin{array}{l}\text { Syncopal attacks; cholelithiasis } \\
\text { Cholelithiasis (operated); duodenal ulcer } \\
\text { Dizziness; hiatus hernia; hypertension }\end{array}$ & $\begin{array}{l}\text { SR-AR with CSM } \\
\text { SR-ant. lat. ischaemia } \\
\text { SR-LVH }\end{array}$ & $\begin{array}{l}\text { PAF } \\
\text { PAT } \\
\text { PAF }\end{array}$ & $\begin{array}{l}\text { Normal } \\
\text { Normal } \\
\text { Normal }\end{array}$ & $\begin{array}{l}\text { Atropine } \\
\text { None } \\
\text { None }\end{array}$ & 3 days \\
\hline 8 & 50 & $M$ & Goitre (colloid-cystic adenoma-operated) & SR-PVC & PAF & Normal & $\begin{array}{l}\text { Digitalis, } \\
\text { propranolol, } \\
\text { quinidine }\end{array}$ & 3 days \\
\hline 9 & 50 & $\mathbf{F}$ & MS; nephrovascular hypertension & SR-LAO & PAF & $3 \cdot 8$ & $\begin{array}{l}\mathrm{KCl} \\
\text { quinidine, } \\
\text { amiodarone }\end{array}$ & 10 days \\
\hline 10 & 71 & $M$ & Dizziness; palpitation & SR-PAC & PAF & Normal & None & - \\
\hline 11 & 60 & $\mathbf{M}$ & Syncopal attacks; rheumatoid arthritis & SB-PAC & - & Normal & None & - \\
\hline
\end{tabular}

AF, atrial fibrillation; AFl, atrial flutter; AR, atrial arrest; ASD, atrial septal defect; CSM, carotid sinus massage; LAO, left atrial overload; LVH, left ventricular hypertrophy; MS, mitral stenosis; N, normal; PAC, premature atrial contraction; PAF, paroxysmal atrial fibrillation; PAT, paroxysmal atrial tachycardia; PVC, premature ventricular contraction; RAO, right atrial overload; RVO, right ventricular overload; SB, sinus bradycardia; SR, sinus rhythm; ND, not discontinued. 
Table 2 Individual data from right atrial monophasic action potential recordings before and after Bunaphtine administration

\begin{tabular}{|c|c|c|c|c|c|c|c|c|c|c|c|}
\hline \multirow{2}{*}{$\begin{array}{l}\text { Case } \\
\text { No. }\end{array}$} & \multirow{2}{*}{ Rhythm } & \multirow{2}{*}{$\begin{array}{l}\text { Dose } \\
\text { (mg/kg } \\
\text { body } \\
\text { weight }\end{array}$} & \multicolumn{3}{|c|}{ Before Bunaphtine } & \multicolumn{3}{|c|}{ After Bunaphtine } & \multicolumn{2}{|c|}{$R A M A P d u r}$. & \multirow{2}{*}{$\begin{array}{l}\begin{array}{l}\text { Cycle } \\
\text { length }\end{array} \\
V C \\
(\%)\end{array}$} \\
\hline & & & $\underset{(\mathrm{ms})}{\operatorname{R} A M A P d u r .}$ & $\begin{array}{l}\text { Cycle length } \\
\text { (ms) }\end{array}$ & $\begin{array}{l}\text { RRR ph3 } \\
(\% / s)\end{array}$ & 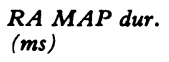 & $\begin{array}{l}\text { Cycle length } \\
\text { (ms) }\end{array}$ & $\begin{array}{l}R R R p h 3 \\
(\% / s)\end{array}$ & $\begin{array}{l}\text { Incr. } \\
(\%)\end{array}$ & $\begin{array}{l}V C \\
\left(\begin{array}{l}0 \\
0\end{array}\right)\end{array}$ & \\
\hline \multirow[t]{2}{*}{$\begin{array}{r}1 \\
2 \\
3 \\
4 \\
5 \\
6 \\
7 \\
8 \\
9 \\
10 \\
11\end{array}$} & $\begin{array}{l}\text { A. Fl } \\
\text { SR } \\
\text { SR } \\
\text { SR } \\
\text { SR } \\
\text { SR } \\
\text { SR } \\
\text { SR } \\
\text { SR } \\
\text { SR } \\
\text { (SR) }\end{array}$ & $\begin{array}{l}0 \cdot 81 \\
2 \\
1 \cdot 3 \\
1 \cdot 5 \\
2 \\
2 \\
1 \cdot 6 \\
2 \cdot 1 \\
1 \cdot 8 \\
1 \cdot 5\end{array}$ & $\begin{array}{l}137 \cdot 8 \pm 16 \cdot 24 \\
217 \cdot 43 \pm 4 \cdot 12 \\
233 \cdot 6 \pm 4 \cdot 16 \\
245 \cdot 6 \pm 7 \cdot 44 \\
261 \pm 7 \cdot 71 \\
286 \cdot 6 \pm 5 \cdot 94 \\
292 \cdot 7 \pm 13 \cdot 65 \\
301 \pm 6 \cdot 52 \\
325 \cdot 72 \pm 27 \cdot 49 \\
354 \pm 8 \cdot 54\end{array}$ & $\begin{array}{l}254 \pm 8 \cdot 22 \\
521 \pm 6 \cdot 08 \\
764 \pm 23 \cdot 29 \\
614 \cdot 4 \pm 5 \cdot 18 \\
577 \pm 2 \cdot 74 \\
815 \cdot 2 \pm 14 \cdot 2 \\
754 \cdot 6 \pm 54 \cdot 77 \\
561 \pm 2 \cdot 24 \\
994 \cdot 5 \pm 45 \cdot 35 \\
917 \pm 9 \cdot 70\end{array}$ & $\begin{array}{l}309 \cdot 12 \pm 39 \cdot 5 \\
615 \cdot 4 \pm 25 \cdot 77 \\
384 \cdot 16 \pm 12 \cdot 4 \\
518 \cdot 31 \pm 50 \cdot 82 \\
478 \cdot 52 \pm 12 \cdot 81 \\
432 \cdot 46 \pm 5 \cdot 35 \\
406 \cdot 1 \pm 17 \cdot 46 \\
493 \cdot 42 \pm 11 \cdot 43 \\
303 \cdot 01 \pm 43 \\
306 \cdot 6 \pm 19 \cdot 23\end{array}$ & $\begin{array}{l}257 \cdot 4 \pm 14 \cdot 89 \\
286 \pm 6 \cdot 52 \\
311 \pm 3 \cdot 08 \\
330 \cdot 8 \pm 3 \cdot 11 \\
305 \cdot 2 \pm 10 \cdot 76 \\
379 \pm 5 \cdot 48 \\
317 \pm 4 \cdot 36 \\
329 \pm 2 \cdot 24 \\
334 \cdot 29 \pm 16 \cdot 73 \\
374 \cdot 4 \pm 9 \cdot 96\end{array}$ & $\begin{array}{c}336 \cdot 2 \pm 4 \cdot 8 \\
596 \pm 11 \cdot 4 \\
680 \pm 14 \cdot 26 \\
624 \cdot 6 \pm 12 \cdot 66 \\
592 \pm 2 \cdot 74 \\
854 \pm 8 \cdot 22 \\
812 \pm 7 \cdot 85 \\
635 \pm 0 \\
1001 \cdot 65 \pm 25 \cdot 85 \\
929 \pm 6 \cdot 52\end{array}$ & $\begin{array}{l}157 \cdot 57 \pm 19 \cdot 21 \\
380 \cdot 29 \pm 29 \cdot 25 \\
259 \cdot 15 \pm 9 \cdot 25 \\
285 \cdot 49 \pm 11 \cdot 29 \\
417 \cdot 75 \pm 5 \cdot 06 \\
282 \cdot 92 \pm 4 \cdot 89 \\
300 \cdot 14 \pm 12 \cdot 63 \\
415 \cdot 42 \pm 7 \cdot 83 \\
298 \cdot 6 \pm 58 \cdot 1 \\
279 \pm 6 \cdot 93\end{array}$ & $\begin{array}{c}86 \cdot 79 \\
31 \cdot 54 \\
33 \cdot 13 \\
34 \cdot 69 \\
16 \cdot 98 \\
32 \cdot 24 \\
8 \cdot 3 \\
9 \cdot 3 \\
2 \cdot 63 \\
5 \cdot 76\end{array}$ & $\begin{array}{l}42 \cdot 8 \\
19 \\
20 \cdot 1 \\
20 \cdot 9 \\
11 \cdot 04 \\
19 \cdot 69 \\
5 \cdot 64 \\
6 \cdot 3 \\
1 \cdot 84 \\
3.96\end{array}$ & $\begin{array}{c}19 \cdot 7 \\
9 \cdot 5 \\
8 \cdot 28 \\
1 \cdot 16 \\
1 \cdot 81 \\
3 \cdot 29 \\
5 \cdot 18 \\
8 \cdot 75 \\
0.51 \\
0.92\end{array}$ \\
\hline & $\begin{array}{l}\text { AP } \\
70 / \min \end{array}$ & 2 & $341 \cdot 86 \pm 5 \cdot 21$ & 840 & $403 \cdot 54 \pm 27 \cdot 88$ & $376.6 \pm 3.65$ & $840 \pm 0$ & $367 \cdot 96 \pm 5 \cdot 9$ & $9 \cdot 22$ & $7 \cdot 02$ & 一 \\
\hline \multicolumn{2}{|c|}{$\begin{array}{l}\text { Mean values } \\
\text { Cases 2-11 }\end{array}$} & $\begin{array}{l}1 \cdot 78 \\
\pm 0 \cdot 28\end{array}$ & $285 \cdot 95 \pm 46 \cdot 3$ & $735 \cdot 8 \pm 161 \cdot 5$ & $434 \cdot 15 \pm 96 \cdot 1$ & $334 \cdot 3 \pm 32 \cdot 42$ & $756 \cdot 4 \pm 149 \cdot 16$ & $328 \cdot 67 \pm 60 \cdot 23$ & $\begin{array}{l}18 \cdot 38 \\
13 \cdot 0\end{array}$ & $\begin{array}{c}11 \cdot 55 \pm \\
7.58\end{array}$ & $\begin{array}{l}4 \cdot 38 \pm \\
3 \cdot 64\end{array}$ \\
\hline
\end{tabular}

AFl, atrial flutter; AP, atrial pacing; dur., duration; incr., increment; MAP, monophasic action potential; RA, right atrial; RRR ph3, reletive repolarisation rate of phase 3 ; SR, sinus rhythm; VC, variation coefficient.

thereafter every minute for a mean observation time of $12 \cdot 2$ minutes.

In case 9 right atrial monophasic action potential recordings were obtained from 5 different sites in order to evaluate the degree of non-uniformity of atrial repolarisation before and after drug administration. In case 11 all the investigations were performed at a constant cycle length obtained by atrial pacing to eliminate the rate dependent variations in duration of right atrial monophasic action potential.

According to the criteria suggested by Olsson (1971) for quantitative analysis of the tracings, right atrial monophasic action potential total duration was measured at 90 per cent of the repolarisation and expressed in milliseconds (ms); preceding electric cycle length was also expressed in milliseconds. The relative repolarisation rate of phase 3 was expressed as a percentage of a second $(\% / s)$.
Statistical analysis was performed using the $t$ test of paired differences and variation coefficients.

\section{Results}

Individual data from recordings before and after Bunaphtine administration are presented in Table 2.

\section{PATIENTS IN SINUS RHYTHM}

Before Bunaphtine the average right atrial monophasic action potential duration was $285.9 \pm 46.3$ $\mathrm{ms}$; the average relative repolarisation rate of phase 3 was $434 \cdot 15 \pm 96 \cdot 1$ per cent/s, and the average cycle length was $735 \cdot 77 \pm 161.9 \mathrm{~ms}$. After the administration of the drug a prolongation of the average duration of right atrial monophasic action potential to $334 \cdot 3 \pm 32 \cdot 82 \mathrm{~ms}$ and of cycle length to $756.43 \pm 149.16 \mathrm{~ms}$ together with a reduction of relative repolarisation rate of phase 3 to $328.67 \pm$ $60 \cdot 23 \mathrm{per}$ cent/s was seen (Fig. 1).

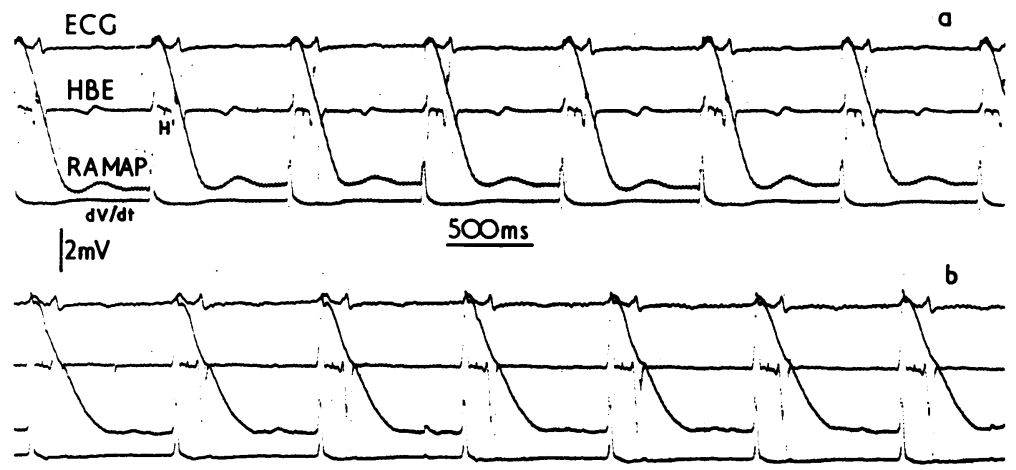

Fig. 1 Case 6. Right atrial monophasic action potential (RAMAP) before (a) and 10 minutes after Bunaphtine (b). 


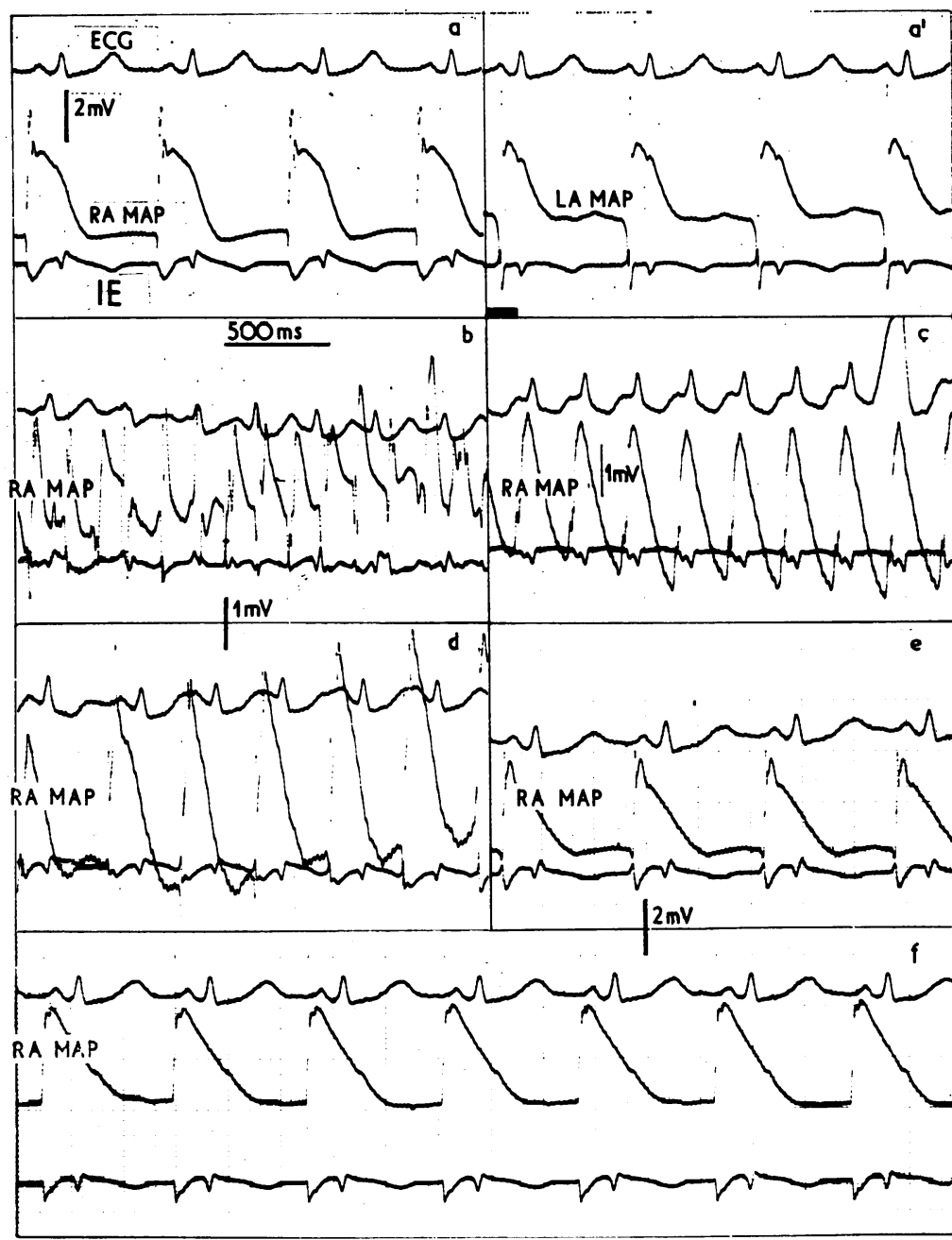

Fig. 2 Case 4. $\left(a-a^{\prime}\right)$ basic sinus rhythm (right and left atrial $M A P s)$; (b) paroxysmal atrial fibrillation; (c) atrial flutter during drug infusion; (d) recovery of sinus rhythm (SR) (1 minute after Bunaphtine administration), (e) $S R 7$ minutes after Bunaphtine administration; (f) 30 minutes after Bunaphtine administration (maximum effect on $R A M A P$ duration). IE, intracardiac electrogram.

The average increment of right atrial monophasic action potential duration was 18.38 per cent. The average variation coefficient for monophasic action potential duration was 11.55 per cent. The largest modification of total duration of right atrial monophasic action potential was noticed at an average time of $8.1 \mathrm{~s}$ (range 2 to $30 \mathrm{~s}$ ) after drug infusion.

In 2 patients (cases 4 and 10) paroxysmal atrial fibrillation occurred during the procedure and Bunaphtine was administered to regain sinus rhythm (Fig. 2 and 3). Conversion occurred in both cases with a progressive lengthening of right atrial monophasic action potential, the critical duration for the re-establishment of sinus rhythm being 195 to $210 \mathrm{~ms}$. In one patient (case 4) a passage from atrial fibrillation to atrial flutter with 1:1 conduction was observed before the conversion to sinus rhythm (Fig. 2c).

In all cases a good relation between total duration of right atrial monophasic action potential and relative repolarisation rate of phase 3 variations was seen (equation for regression line $y=844 \cdot 3-1 \cdot 5 x$ $r=0.72$ ) (Fig. 4).

Variations of total duration of right atrial monophasic action potential and those of cycle length were poorly correlated $(y=114.9+2.03 x ; r=0.61)$.

Prolongation of right atrial monophasic action potential and relative repolarisation rate reduction were significant $(P<0.0025)$, while cycle length modifications were not $(P>0 \cdot 05)$.

In case 9 the interindividual variation coefficient in basal conditions was 8.75 per cent; after Bunaph- 

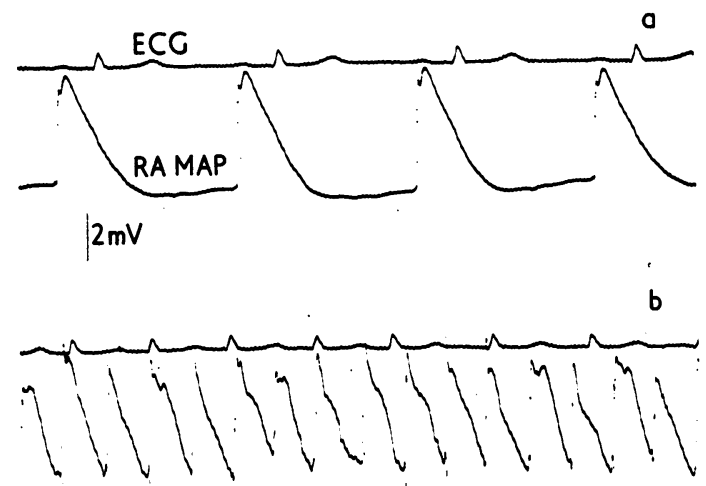

$500 \mathrm{~ms}$

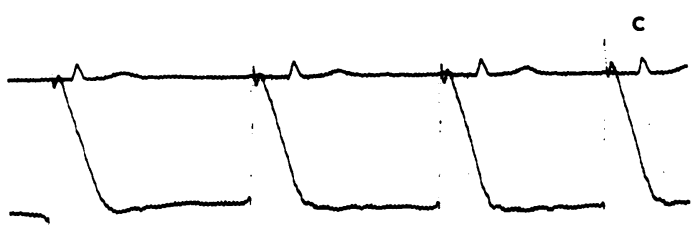

d

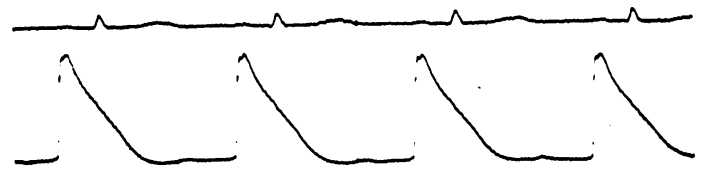

Fig. 3 Case 10. (a) Basic sinus rhythm; (b) paroxysmal atrial fibrillation; (c) $R A M A P$ immediately after SR re-establishment; (d) RA MAP 4 minutes after Bunaphtine administration (maximum effect on duration).

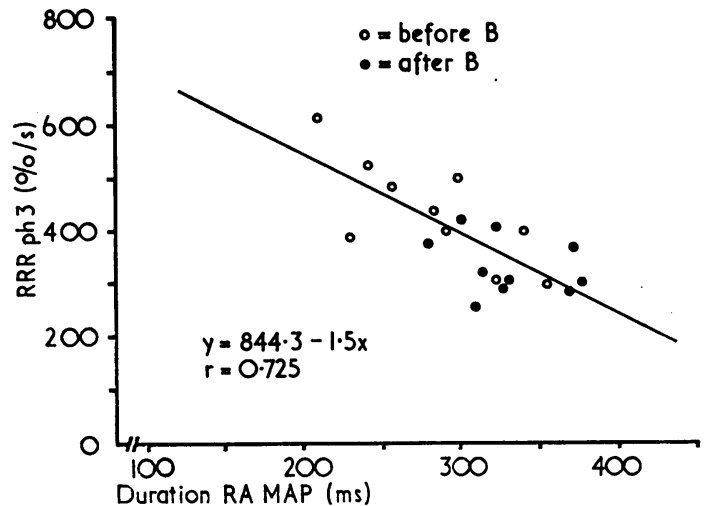

Fig. 4 Relation between relative repolarisation rate of phase 3 (RRR ph3) and duration of right atrial $M A P$ (RA MAP TD).

tine administration this was reduced to 5 per cent. In this case the lowest increment in total duration of right atrial monophasic action potential was observed $(2.63 \%)$. In case 11 the increment was 9.2 per cent, with a variation coefficient of 7 per cent; the interindividual variation coefficient before drug administration was 4.19 per cent.

PATIENT IN ATRIAL FLUTTER (FIG. 5)

(This case was not included in the statistical evaluation because previous cardioactive treatment had not been withdrawn and could have distorted the results.)

Basal right atrial monophasic action potential total duration was $137.8 \mathrm{~ms}$; after Bunaphtine prolongation up to $257.4 \mathrm{~ms}$ was observed without

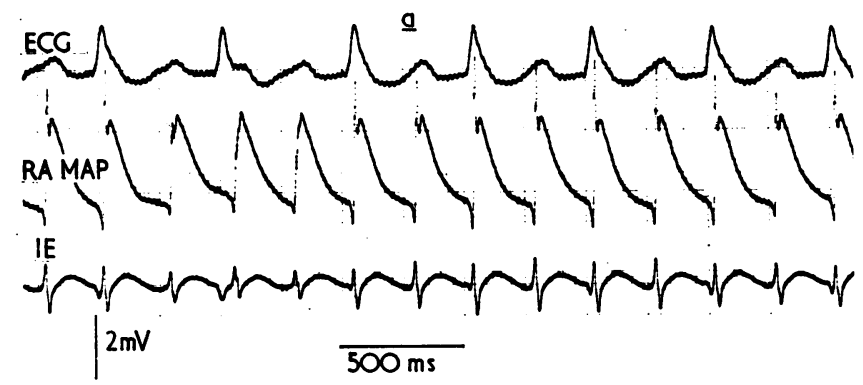

Fig. 5 Case 1. Persistence of atrial flutter in spite of significant RA MAP prolongation after Bunaphtine (b). IE, intracardiac electrogram.

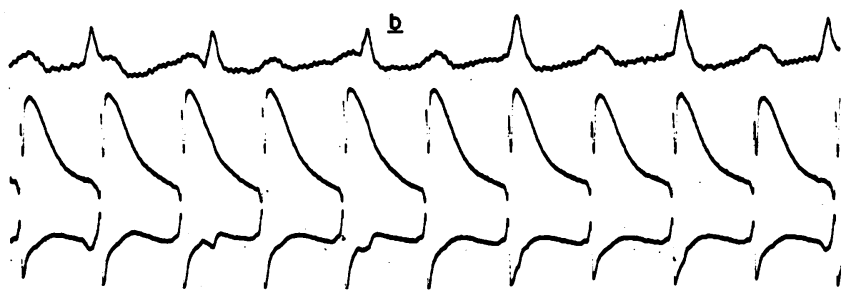


conversion to sinus rhythm. The increment of right atrial monophasic action potential total duration was 86.79 per cent and was strongly related to a significant prolongation of cycle length $(y=210 \cdot 1+$ $1.37 x ; r=0.99$ ).

\section{Discussion}

A short monophasic action potential duration has been shown to be present in a number of patients with paroxysmal supraventricular arrhythmias (Olsson, 1972; Olsson et al., 1973). In our study only 4 of the 10 patients in sinus rhythm had a rather short right atrial monophasic action potential; the shortest monophasic action potential was found in a patient with a clinical picture of hyperthyroidism in accord with in vitro observations (Freedberg et al., 1970; Johnson et al., 1973).

Bunaphtine administration induced a significant prolongation of right atrial monophasic action potential (average $18.38 \%$ ). As can be seen from Table 2 the largest increment was in patients with a short basic repolarisation (average $29 \%$ ), while a smaller effect (average $7 \cdot 1 \%$ ) resulted when basic right atrial monophasic action potential duration was within normal range. Prolongation of the right atrial monophasic action potential can in part be explained by a significant reduction in heart rate if it occurs (Olsson, 1971); in our study, however, only a slight increase in cycle length was found which was not statistically significant. A clear-cut correlation between right atrial monophasic action potential prolongation and heart rate reduction was evident only in case 1 . When the heart rate was maintained constant by atrial pacing (case 11), an increase in total duration of right atrial monophasic action potential $(7 \%)$ was still seen. This implies that Bunaphtine induces to a certain extent a prolongation of right atrial monophasic action potential as a direct effect. A reduction of relative repolarisation rate of phase 3, strongly correlated to prolongation of right atrial monophasic action potential, was seen after drug infusion in all cases.

The processes governing the shape and duration of repolarisation of cardiac action potential are complex and controversial and have recently been described in a mathematical model (McAllister et al., 1975).

As acetylcholine enhances $\mathrm{K}^{+}$permeability in the atrial myocardium (Hoffman and Cranefield, 1960), and vagal stimulation induces a reduction in duration of right atrial monophasic action potential (Samuelsson, 1973) so that the effect of Bunaphtine could be explained as an indirect action on atrial repolarisation by a vagolytic effect; but pharmaco- logical studies contradict this hypothesis (Beani, 1972; Sanna et al., 1974).

The prolongation of repolarisation was most consistent when the basic refractory period was short. In addition to prolonging the duration of atrial repolarisation Bunaphtine also reduced the degree of variation in this duration as recorded from different sites in the same atrium. This normalisation of refractoriness may result in the blocking of re-entry pathways in the atrium leading to an antiarrhythmic effect as a result of the reduction of inhomogeneity of repolarisation. In the 2 patients who developed paroxysmal atrial fibrillation during the procedure (cases 4 and 10), conversion to sinus rhythm was seen during drug infusion, when the duration of right atrial monophasic action potential reached about $200 \mathrm{~ms}$; this value is critical for the re-establishment of sinus rhythm (Gavrilescu and Cotoi, 1972; Olsson, 1972). Immediately after recovery of sinus rhythm the right atrial monophasic action potential duration was still short (Fig. $2 \mathrm{~d}$ to $3 \mathrm{c}$ ), and there was a tendency to repetitive arrhythmias. After the final drug-induced normalisation of monophasic action potential duration, full stability of rhythm was achieved (Fig. $2 \mathrm{f}$ to $3 \mathrm{~d}$ ). Persistence of atrial flutter in case 1 , in spite of the significant prolongation of right atrial monophasic action potential (Fig. 5b), is not clear and seems to contradict the observations in the other 2 patients. It could be related to the lower dose employed, which was sufficient to reduce heart rate. Monophasic action potential prolongation, therefore, could be explained as a rate-dependent modification. Moreover in this patient the effect of other cardioactive drugs was already present.

As stated by Olsson (1971, 1974) the expected variability in a single subject of the atrial monophasic action potential duration between successive applications of the suction electrode can be expressed as a variation coefficient ranging from 0 up to 16.5 per cent. In our patients, with at least 5 applications of the electrode at different sites of the right atrium, an intraindividual variation coefficient ranging from 3.3 to 8.75 per cent was found; this was considered to be an expression of the range of variability of repolarisation duration in the basal condition.

An increased variability or inhomogeneity of the repolarisation of the myocardial fibres may allow development of a re-entry mechanism which could lead to arrhythmias (Sarachek et al., 1972; Wit et al., 1974). In case 9 right atrial monophasic action potential duration was well within normal limits but a wide intraindividual variation coefficient was found $(\mathrm{VC}=8.75 \%)$, which could account for the clinical picture. After Bunaphtine, the intraindividual variation coefficient was lessened 


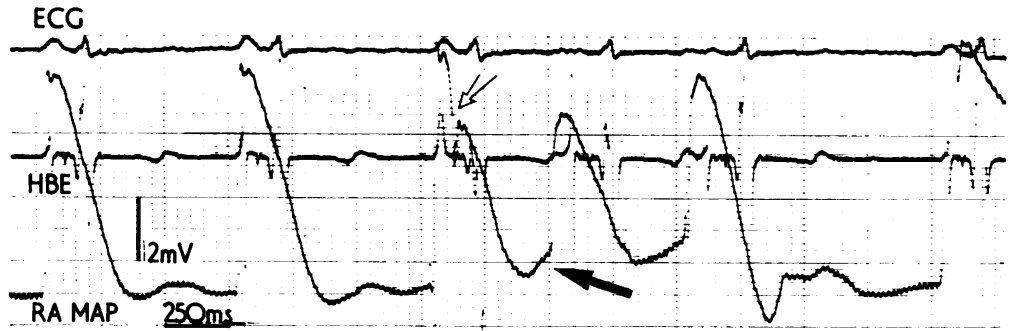

Fig. 6 Evidence of phase 4 depolarisation (black arrow) during a run of premature atrial contractions. (An atrial fusion beat is also appreciable: white arrow.)

(VC $=5 \%$ ), suggesting a reduced dispersion of repolarisation; this suggests that an alternative action of the drug is to improve the spread of the excitatory wave-front. To test this hypothesis would require further investigations with a more appropriate technique, such as proposed by Sarachek et al. (1972).

Variation coefficients between monophasic action potential durations before and after Bunaphtine were also calculated in individual patients and were employed as an index of the significance of the drug's effect. A higher variation coefficient was found in patients with a shorter duration of right atrial monophasic action potential (average $17.85 \%$ ), while a lower one was observed in those with a normal repolarisation (average $4.95 \%$ ).

A slow phase 4 depolarisation, suggestive of latent pacemaker activity (Hoffman and Cranefield, 1960), was found in 3 patients; it was much more evident during a run of premature atrial beats (Fig. 6). After Bunaphtine administration a reduction of prepotential was apparent from inspection of the tracings, but, because of technical limitations, no quantitative evaluation was possible.

The classification of antiarrhythmic drugs is still controversial. Most authors favour an electrophysiological approach (Mason et al., 1973; Sanna et al., 1974; Singh and Hauswirth, 1974; Vaughan Williams, 1975). Monophasic action potential recording alone does not allow an exhaustive evaluation of all properties of an antiarrhythmic drug. It provides information about the local action potential duration, repolarisation uniformity, and instantaneous modifications of cellular refractoriness. Using a pacing technique, an evaluation of the effects of the drug on the effective refractory period/ monophasic action potential duration ratio could also be accomplished. Bunaphtine should increase this ratio (Sanna et al., 1974).

In previous electrophysiological clinical studies a depressive effect of Bunaphtine on intra-atrial conduction velocity has been shown (Scibilia et al., 1973; Grazi et al., 1974). The present work appears to confirm, in the human beating heart, what has been observed in in vitro investigations (Ferroni et al., 1973), regarding the Bunaphtine-induced prolongation of atrial action potentials. As far as atrial tissue is concerned, therefore, Bunaphtine is a class 3 antiarrhythmic drug according to the classification of Vaughan-Williams (Vaughan Williams, 1975).

\section{References}

Beani, L. (1972). Profilo farmacologico di un nuovo antiaritmico: la Bunaftide. Bollettino della Società Italiana di Cardiologia, 17, 1279-1281.

Botti, G. (1972). Un nouveau medicament antiarythmique: la Bunaftine. Experience clinique de plusieurs centres cardiologiques. In Actas del VI Congresso Europeo de Cardiologia, p. 532.

Botti, G., Bonatti, V., Finardi, A., Lazzeroni, E., and Ghinelli, L. (1976). Experimentation clinique de l'action prophylactique et thérapeutique de la Bunaftine sur les arythmies de la phase algue de l'infarctus du myocarde. Annales de Cardiologie et d'Angeiologie, 25, 3.

Cabasson, J., Mellet, J. M., Guimond, C., Bachy, C., Sassine, A., and Puech, P. (1975). L'étude des potentiels de action monophasique du myocarde par voie endocavitaire et ses applications. Annales de Cardiologie et d'Angéiologie, 24, 483.

Fenici, R., Bellocci, F., Zecchi, P., Fiorentini, R., Gabrielli, L., and Carbonin, P. U. (1974a). Effect of Bunaphtine on human atrial MAP. Acta Medica Romana, 12, 75.

Fenici, R., Bellocci, F., Zecchi, P., Gabrielli, L., and Carbonin, P. U. (1973). Monophasic action potential of human heart. Preliminary results with a new technique. Acta Medica Romana, 11, 312,

Fenici, R., Bellocci, F., Zecchi, P., and Zeppilli, P. (1975). La registrazione del potenziale monofasico del cuore destro nell'uomo: suo possibile impiego nella interpretazione delle aritmie. Comunicazione al XXXVI Congresso della Società Italiana di Cardiologia.

Fenici, R., Franceschini, A., Bellocci, F., Gabrielli, L., and Carbonin, P. U. (1974b). Right atrial MAP from human heart: a case of paroxysmal atrial fibrillation. Acta Medica Romana, 12,

Ferroni, A., and Monticelli, G. (1973). Electrophysiological aspects of the action of Bunaphtide on single cardiac muscle fibers. Pharmacological Research Communications, 5, 151-173.

Franchini, G., Storelli, A., Pierfelice, O., Latorre, A., Fiandanese, F., and Rizzon, P. (1974). Attività antiaritmica della Bunaftine. Bollettino della Società Italiana di Cardiologia, 19, 427-433.

Freedberg, A. S., Papp, J. Gy., and Vaughan Williams, E. M. (1970). The effect of altered thyroid state on atrial intracellular potentials. Fournal of Physiology, 207, 357-369. 
Gavrilescu, S., and Cotoi, S. (1972). Monophasic action potential of right human atrium during atrial flutter and after conversion to sinus rhythm. Argument for re-entry theory. British Heart fournal, 34, 396-402.

Grazi, S., Romano, S., Bonazzi, O., Pozzoni, L., Cavoretto, D., and Gardumi, M. (1975). Studio elettrofisiologico dei disturbi della conduzione intraventricolare nella fase post-acuta dell'infarto del miocardio. Comunicazione al XXXVI Congresso della Società Italiana di Cardiologia.

Grazi, S., Romano, S., Bonazzi, O., Pozzoni, L., Cavoretto, D., Gardumi, M., and Sardella, F. (1974). Effetti di un nuovo farmaco antiaritmico, la Bunaftine, sulla conduzione intra-atriale, atrioventricolare ed intraventricolare dello stimolo. Cardiologia Pratica, 25, 312-216.

Hoffman, B. F., and Cranefield, P. F. (1960). Electrophysiology of the Heart. McGraw-Hill, New York.

Hoffman, B. F., Cranefield, P. F., Lepeschkin, E., Surawicz, B., and Herrlich, H. C. (1959). Comparison of cardiac monophasic action potentials recorded by intracellular and suction electrodes. American fournal of Physiology, 196, 1297-1301.

Johnson, P. N., Freedberg, A. S., and Marshall, J. M. (1973) Action of thyroid hormone on the transmembrane potentials from sino-atrial node cells and atrial muscle cells in isolated atria of rabbits. Cardiology, 58, 273-289.

Lotto, A., and Lomanto, B. (1972). Prime esperienze sullo impiego clinico di un nuovo antiaritmico: la Bunaftide. Bollettino della Società Italiana di Cardiologia, 17, 701.

McAllister, R. E., Noble, D., and Tsien, R. W. (1975). Reconstruction of the electrical activity of cardiac Purkinje fibres. Fournal of Physiology, 251, 1-59.

Masini, G., Cuccu, E., and Zanetti, L. (1972). Sull' impiego della Bunaftine nel trattamento ambulatoriale di alcuni disturbi del ritmo. Bollettino delıa Società Italiana di Cardiologia, 17, 12.

Mason, D., Amsterdam, E. A., Massumi, R. A., Mansur, E. J., Hughes, J. L., III., and Zelis, R. (1973). Combined actions of antiarrhythmic drugs. Electrophysiological and therapeutic consideration. In Cardiac Arrhythmias, p. 531. Ed. by L. S. Dreifus and W. Likoff. Grune and Stratton, New York.

Olsson, S. B. (1971). Monophasic Action Potential of Right Heart. Suction Electrode Method in Clinical Investigation. Elanders Boktrykery Ab, Goteborg.
Olsson, S. B. (1972). Recording of monophasic action potentials in the study of atrial dysrhythmias. Giornale Italiano di Cardiologia, 2, 536-541.

Olsson, S. B. (1974). Atrial repolarization in man. Effect of beta-receptor blockade. British Heart fournal, 36, 806-810.

Olsson, S. B., Brorson, L., and Varnauskas, E. (1973). Class 3 antiarrhythmic action in man. Observations from monophasic action potential recordings and amiodarone treatment. British Heart fournal, 35, 1255-1259.

Samuelsson, R. (1973). Effects of severe systemic hypoxia on myocardial excitation. Acta Physiologica Scandinavica, 88, 267-280.

Sanna, G. P., Lomanto, B., and Rossi, A. (1974). Basi elettrofisiologiche dell'azione dei farmaci antiaritmici. Minerva Cardioangiologica, 22, 731-758.

Sarachek, N. S., Roberts, J., and James, J. L. (1972). A new method to measure non-uniformity in the intact heart. fournal of Electrocardiology, 5, 341-348.

Scibilia, G., Bonatti, V., Pavarani, A., Tagliavini, S., and Botti, G. (1973). Effetto sul fascio di His di una nuova sostanza antiaritmica, la Bunaftine. Cardiologia Pratica, 24, 79-84.

Shabetai, R., Surawicz, B., and Hammill, W. (1968). Monophasic action potentials in man. Circulation, 38, 341-352.

Singh, B. N., and Hauswirth, O. (1974). Comparative mechanisms of action of antiarrhythmic drugs. American Heart fournal, 87, 367-382.

Vaughan Williams, E. M. (1975). Classification of antidysrhythmic drugs. Pharmacology and Therapeutics $B, 1$, 115-138.

Vegis, D. (1975). La Bunaftine nel trattamento delle aritmie. Cardiologia Pratica, 26, 29.

Wit, A., Rosen, M., and Hoffman, B. (1974). Electrophysiology and pharmacology of cardiac arrhythmias. II. Relationship of normal and abnormal electrical activity of cardiac fibers to the genesis of arrhythmias. B. Re-entry. Section 1. American Heart Fournal, 88, 664-670.

Requests for reprints to Dr. R. Fenici, Servizio di Cardiologia, Universita Cattolica del S. Cuore, Roma, Largo Gemelli 8, Italy. 